\title{
Yeast isolation and identification during on-farm cocoa natural fermentation in a highly producer region in northern Brazil
}

Isolamento e identificação de leveduras durante a fermentação natural de cacau em uma região altamente produtora no norte do Brasil

\author{
G. C. A. Chagas Junior ${ }^{1 *}$; J. C. A. do Espírito-Santo² ; N. R. Ferreira ${ }^{1}$; S. H. \\ Marques-da-Silva ${ }^{3}$; G. Oliveira ${ }^{4}$ S. Vasconcelos ${ }^{4}$; S. F. O. de Almeida ${ }^{5}$; L. R. C. \\ Silva $^{1}$; R. M. Gobira ${ }^{6}$; H. M. de Figueiredo ${ }^{1}$; A. S. Lopes ${ }^{1 *}$ \\ ${ }^{1}$ Laboratório de Processos Biotecnológicos (LABIOTEC), Programa de Pós-graduação em Ciência e Tecnologia de \\ Alimentos (PPGCTA), Instituto de Tecnologia, Universidade Federal do Pará, 66075-110, Belém-PA, Brasil \\ ${ }^{2}$ GranBio S.A., Tecnologias Industriais em Biocombustíveis Lignocelulósicos e Renováveis, 01452-000, São Paulo- \\ SP, Brasil \\ ${ }^{3}$ Laboratório de Micologia, Seção de Bacteriologia e Micologia, Instituto Evandro Chagas (IEC/SVS/MS), 67030- \\ 000, Ananindeua-PA, Brasil \\ ${ }^{4}$ Instituto Tecnológico Vale, 66055-090, Belém-PA, Brasil \\ ${ }^{5}$ Curso de Nutrição, Escola Superior Madre Celeste (ESMAC), 67133-018, Ananindeua-PA, Brasil \\ ${ }^{6}$ Laboratórios de Pesquisa Sistemática em Biotecnologia e Biodiversidade Molecular, Instituto de Ciências Exatas e \\ Naturais (ICEN), Universidade Federal do Pará, 66075-110, Belém-PA, Brasil \\ *chagasjunior.gca@gmail.com / alessalopes@ufpa.br
}

(Recebido em 08 de outubro de 2020; aceito em 11 de dezembro de 2020)

\begin{abstract}
The cocoa seeds from Brazilian Amazon are recognized for the high international market value in addition to the desirable aroma and taste. We aimed to identify yeast cultures in a natural cocoa fermentation process in one of the Amazonian regions of great importance in the cocoa beans market. Natural fermentation was carried out for seven days according to the methodologies of the producer and at $24 \mathrm{~h}$ intervals, seed samples were collected and physical-chemical and microbiological analyzes were performed. The contents of lipids, proteins, ash and moisture did not differ $(p \geq 0.05)$ differently from temperature, $\mathrm{pH}$ and total titratable acidity $(p \leq 0.05)$. We identified three species in the fermentation: Pichia kudriavzevii, Torulaspora delbrueckii and Saccharomyces cerevisiae, the most common being during the process. We can verify the importance of knowing the microbiota active in cocoa fermentation to propose improvements during this process of great economic importance for the Amazon region.

Keywords: Amazon region, chocolate, Saccharomyces
\end{abstract}

As sementes de cacau da Amazônia brasileira são reconhecidas pelo alto valor no mercado internacional, além do aroma e sabor desejáveis. Nosso objetivo foi identificar culturas de leveduras em um processo de fermentação natural do cacau em uma das regiões amazônicas de grande importância no mercado de grãos de cacau. A fermentação natural foi realizada por sete dias de acordo com as metodologias do produtor e em intervalos de 24 horas foram coletadas amostras de sementes e realizadas análises físico-químicas e microbiológicas. Os teores de lipídios, proteínas, cinzas e umidade não tiveram diferença estatística ( $p \geq$ $0,05)$ diferentemente da temperatura, $\mathrm{pH}$ e acidez total titulável $(p \leq 0.05)$. Identificamos três espécies na fermentação: Pichia kudriavzevii, Torulaspora delbrueckii e Saccharomyces cerevisiae, sendo a mais comum durante o processo. Podemos verificar a importância de se conhecer a microbiota ativa na fermentação do cacau para propor melhorias durante este processo de grande importância econômica para a Região Amazônica.

Palavras-chave: Região Amazônica, chocolate, Saccharomyces 


\section{INTRODUCTION}

Fermentation is one of the first steps in in chocolate manufacturing from cocoa (Theobroma cacao L.) seeds. The combination of wooden boxes and the practice of turning for five to seven days is a traditional procedure still widely used [1]. The fermentation process occurs spontaneously in the presence of different microorganisms, with the predominance of yeasts, lactic bacteria and acetic bacteria [2].

The diversity of yeasts present in cocoa fermentation is usually associated with the locality and process conditions (available nutrients, $\mathrm{pH}$, temperatures, oxygen, etc.) that directly influence the fermenting bacteria and yeasts' activity. Several studies reveal a wide diversity of yeasts in cocoa fermentation in different countries $[3,4]$.

The follow-up of some parameters is used as a reference for successful fermentation, among them: processing time, temperature of the environment and the mass, turning, $\mathrm{pH}$ and the acidity of the pulp, the fermentation system and existing microbiota [5].

Yeasts are the first microorganisms active in the fermentation process of cocoa beans, which convert the sugars present in the pulp into ethanol and produce enzymes that degrade the pectin present in the pulp, favouring the growth conditions of other microorganisms [6]. Therefore, isolating and identifying them is of great importance to assess their diversity and distribution during cocoa fermentation.

The diversity of fungal microorganisms in the Amazon region is wide and recent studies on cocoa fermentation prove this. The first researches about the identification and performance of yeasts and molds during cocoa fermentation in the Brazilian Amazon were in the cities of Medicilândia and Tucumã (both in Pará state), also reporting the role of enzymatic production in the fermentation process [7, 8]. On the other hand, Serra et al. (2019) [9] identified the cocobiota in Pará state through metagenomic analysis, a pioneering study in the region.

In 2019, the state of Pará returned to the leadership of cocoa production in Brazil, with around 135 thousand tons harvested from the fruit. Which is the result of climatic favours, control of the spread of witches' broom and greater competitiveness in the market [10].

This study aimed to identify the active yeasts during the fermentation of cocoa beans from Tomé-Açu, State of Pará, Brazil, one of the largest chocolate producing regions in the Brazilian Amazon.

\section{MATERIAL AND METHODS}

\subsection{Material and Fermentation Assay}

Cocoa fruits of the Forastero variety were harvested in a local property of Tomé-Açu, Pará State, Brazil $\left(02^{\circ} 28^{\prime} 41.3^{\prime \prime}\right.$ S and $\left.48^{\circ} 16^{\prime} 50.7^{\prime \prime} \mathrm{W}\right)$ and manually opened with stainless steel knives $48 \mathrm{~h}$ after the harvest. The fermentation process was carried out during seven days $(168 \mathrm{~h})$ and after this period, cocoa beans were submitted to a natural drying process. Approximately $90 \mathrm{~kg}$ of cocoa seeds were divided into three wooden boxes $(n=3)$ with dimensions of $1.0 \mathrm{~m}$ length $\times$ $0.40 \mathrm{~m}$ width $\times 0.30 \mathrm{~m}$ height. The boxes were covered by banana leaves and burlap bags to keep the storage fermentation temperature. Both did not undergo any previous hygiene treatment in order to maintain the natural microbiological conditions in order to serve as natural inocula of microorganisms, providing the start the natural fermentation process in the boxes.

After $48 \mathrm{~h}$ from the beginning of the process, cocoa seeds were turned in the boxes, to enable oxygenation and to facilitate the aerobic microorganisms adaptation into the medium.

The temperature of fermentation was measured at five random points (considering the surface, the middle and the bottom) in each fermentation time. Around $100 \mathrm{~g}$ of seed samples were collected from each temperature measurement point and were stored in sterile polyethylene bags and kept under refrigeration $\left(4 \pm 2{ }^{\circ} \mathrm{C}\right)$. At the end of the fermentation process, the samples were chilled and sent to the Laboratory of Biotechnological Processes/UFPA (Belém, Pará, Brazil), where they were frozen $\left(-18 \pm 2{ }^{\circ} \mathrm{C}\right)$ for physical-chemical analysis and refrigerated $\left(4 \pm 2{ }^{\circ} \mathrm{C}\right)$ for microbiological analysis. 


\subsection{Methods}

\subsubsection{Obtaining yeasts from banana leaves}

Sterile swabs were rubbed in random areas $\left(25 \mathrm{~cm}^{2}\right)$ on the banana leaves used in the fermentation process of the cocoa [11]. The swabs were placed in conical Falcon type tubes, containing $25 \mathrm{~mL}$ of peptone water (pH 7.20, Kasvi, São José dos Pinhais, PR, Brazil), added with $15 \%$ sterile glycerol and kept under freezing $\left(-18^{\circ} \mathrm{C}\right)$ until the moment of analysis. The tubes were vortexed for 2 minutes for cell detachment, being inoculated directly via spread plate technique in petri dishes with Potato Dextrose Agar (PDA, pH 5.6, Himedia, Mumbai, India) with chloramphenicol (Sigma-Aldrich Chemical Co., St. Louis, MO, USA, $100 \mathrm{mg} / \mathrm{L}$ ) to inhibit the bacterial growth and were incubated inverted for $72 \mathrm{~h}$ at $30^{\circ} \mathrm{C}$.

\subsubsection{Obtaining yeasts during fermentation}

During the fermentation process, at intervals of $24 \mathrm{~h}$, aliquots of cocoa beans were collected until the end of this stage, totalizing $168 \mathrm{~h}$ of natural fermentation ( 7 days). During the first 48 hours of fermentation, analyses were performed at four hours intervals because the predominant yeast activity in this period of time is elucidated in the literature $[3,6]$.

Twenty grams of cocoa beans samples were aseptically macerated and homogenized in 180 $\mathrm{mL} 0.1 \%$ peptone water (Kasvi) for 2 min obtaining the dilution of $10^{-1}$. In sequence, decimal serial dilutions were taken until $10^{-8}$. Subsequently, $1 \mathrm{~mL}$ of each serial dilution was inoculated into sterile petri dishes via pour-plate technique and homogenised with PDA agar (Himedia) [8] supplemented with chloramphenicol (Sigma-Aldrich Chemical Co., $100 \mathrm{mg} / \mathrm{L}$ ). The inoculated plates were incubated at $30{ }^{\circ} \mathrm{C}$ for $48 \mathrm{~h}$. The result of the plate count was expressed in log CFU $\mathrm{g}^{-1}$ of cocoa beans.

Ten colonies randomly chosen out of twenty to fifty colonies were collected after incubation $\left(30{ }^{\circ} \mathrm{C}\right.$ for $96 \mathrm{~h}$ ) for each petri dish for all times of fermentation. The colonies were picked via the depletion technique twice in sterile petri dishes containing PDA agar and incubated for $72 \mathrm{~h}$ at 30 ${ }^{\circ} \mathrm{C}$.

\subsubsection{DNA extraction and Polymerase Chain Reaction (PCR)}

The genomic DNA of the yeasts was extracted using the AxyPrep kit (Axygen, New York, USA) according to the manufacturer's instructions. The extracted and purified DNAs were stored under freezing $\left(-18^{\circ} \mathrm{C}\right)$ for further analysis.

Aliquots of the extracted DNA, were added to a solution containing ultrapure water (Ambion, Austin, TX, USA), 10× buffer solution (Invitrogen, Carlsbad, CA, USA), dNTP mix $10 \mathrm{mM}$ (Invitrogen), $\mathrm{MgCl}_{2} 50 \mathrm{mM}$ (Invitrogen) and Taq DNA polymerase $5 \mathrm{U} / \mu \mathrm{L}$ (Invitrogen). The $5.8 \mathrm{~S}$ - Internally Transcribed Spacer (5.8S-ITS) region was amplified by the PCR analysis with the pair of primers ITS-1 (forward) (5'-TCCGTAGGTGAACCTGCGG-3') and ITS-4 (reverse) (5'TCCTCCGCTTATTGATATGC-3') (Invitrogen) [12, 13] at a final concentration of 10 pmol each. The PCRs conditions, adapted based in Fujita et al. (2011) [12], Chang et al. (2001) [14] and Chen et al. (2001) [15] studies were: initial denaturation at $95^{\circ} \mathrm{C}$ for 5 ', 35 cycles of $94{ }^{\circ} \mathrm{C}$ for $1^{\prime}, 55.5^{\circ} \mathrm{C}$ for $2^{\prime}, 72^{\circ} \mathrm{C}$ for $2^{\prime}$ and a final extension at $72{ }^{\circ} \mathrm{C}$ for $10^{\prime}$, performed in a Labtrace thermocycler (model K960, Hangzhou, Zhejiang, China).

The PCR products were purified sequentially with isopropanol $65 \%$ and ethanol $70 \%$ at 1.800 $\times g$ and $10{ }^{\circ} \mathrm{C}$ for $45 \mathrm{~min}$ and $10 \mathrm{~min}$, respectively. Afterwards, the cycle sequencing reactions were performed with $\sim 20 \mathrm{ng}$ of amplified DNA using the Big Dye Terminator kit v. 3.1 (ThermoFisher Scientific, Waltham, MA, USA), as recommended by the manufacturer. The bi-directional reactions were sequenced and read in an ABI 3730 DNA Analyzer (Thermo-Fisher Scientific). Afterwards, bi-directional reads were assembled to generate FASTA sequences in Geneious R10 (Biomatters, Auckland, New Zealand) and then aligned in MAFFT v. 7.2 [16]. 
The phylogenetic analysis based on maximum likelihood was conducted using the PHYML package (using the GTR + G substitution model, with 1,000 bootstrap replicates) [17] implemented in Geneious R10. All the sequences were submitted for the GenBank database (https://www.ncbi.nlm.nih.gov).

\subsubsection{Physico-chemical analysis of the cotyledons}

The husks and the embryo of cocoa seeds were extracted and the cotyledons were grounded using an analytical mill (model A11b, Ika, Staufen, Germany). Titratable acidity (TTA - 31.06.06, AOAC), pH (970.21, AOAC), moisture (931.04, AOAC), ash (972.15, AOAC), total lipids (963.15 AOAC) and proteins (970.22 AOAC) were measured according to the Association of Official Analytical Chemists - AOAC [18]. Moisture, ash, total lipids and the proteins analyses, were carried out only at the beginning and at the end of the fermentation process, because the values of these analyses do not present a considerable variation during the process. All analyses were carried out in triplicates.

\subsubsection{Statistical Analysis}

Replicates analyses (temperature of fermentation, $\mathrm{pH}$ and titratable acidity) were submitted to analysis of one-way ANOVA followed by comparison by Tukey test $(p \leq 0.05)$. The statistical analyses were undertaken using the Statistica 7.0 software (StatSoft, Inc., Tulsa, USA).

\section{RESULTS AND DISCUSSION}

\subsection{Diversity of yeasts during the cocoa fermentation}

Two yeasts species were isolated from the banana leaves used in the fermentation process of cocoa beans. Banana leaves showed, on average, a yeast count of $2.7 \log \mathrm{CFU} / \mathrm{cm}^{2}$. The isolates were Pichia kudriavzevii and Torulaspora delbrueckii species (Table 1). A total of 32 yeast isolates were obtained during the fermentation process. Four species were identified: Pichia kudriavzevii (5 strains; $15.6 \%$ of the strains), Torulaspora delbrueckii (2 strains, $6.3 \%$ of the strains) and Saccharomyces cerevisiae (24 strains, $75.0 \%$ of the strains). The presence of the Trichosporon asahii can probably be considered environmental contamination (one strain; $3.1 \%$ of the strains) (Table 1).

The composition of the yeast species during the fermentation process is directly responsible for the development of the chocolate flavour and aroma. Several species have been characterized during the fermentation process.

The count value found in this study is within the count range reported by Papalexandratou et al. (2011) [19], who studied spontaneous fermentations in cocoa troughs in Ecuador, found counts on the surface of plant materials (fruits and leaves). Fernández Maura et al. (2016) [20] studied the diversity of environmental and intrinsic yeasts from cocoa bean fermentations in Cuba, and found that environmental samples (equipment and vegetable surfaces) showed a greater diversity of yeasts compared to fermentations.

Banana leaves are used empirically to reduce heat losses during fermentation or to avoid contact of the seeds with the soil, in case of fermentation in heaps and are known to be an essential source of yeast initiating the fermentation process. Since most of the microorganisms that naturally contaminate the seeds come mainly from wooden boxes with residues from previous fermentations and banana leaves, placed on top of the troughs during fermentation $[6,21]$.

The yeast species composition during the fermentation process is directly responsible for developing flavour and aroma of chocolate. Several species have been characterized during the fermentation process and we identified four species during the fermentation process. Recently, Serra et al. (2019) [9] identified the microbial population of cocoa fermentation in Pará state by metagenomic analysis and found results similar to this study: the presence of $S$. cerevisiae, $P$. kudriavzevii and T. asahii (Table 1). 
Table 1. Species identification of isolated yeasts from banana leaves and the fermentation process of cocoa seeds in the Brazilian Amazon using ITS sequences. BLAST n scores, e-values and pair wise identities are shown for the obtained ITS sequences matched against the ITS sequences of the type strains of Pichia kudriavzevii (CBS 5147, KY104577.1), Saccharomyces cerevisiae (CBS 1171, NR_111007.1), Torulaspora delbrueckii (CBS 1146, NR_111257.1) and Trichosporon asahii (CBS2479, NR_073341.1).

\begin{tabular}{|c|c|c|c|c|}
\hline Isolate & $\begin{array}{l}\text { GenBank } \\
\text { accession }\end{array}$ & Score $(\%)$ & E-value & $\begin{array}{c}\text { Pairwise } \\
\text { identity }(\%)\end{array}$ \\
\hline \multicolumn{5}{|c|}{ Banana Leaves } \\
\hline Pichia kudriavzevii & MT121010 & 100 & 0.0 & 100 \\
\hline Pichia kudriavzevii & MT121011 & 100 & 0.0 & 100 \\
\hline Torulaspora delbrueckii & MT121012 & 100 & 0.0 & 100 \\
\hline \multicolumn{5}{|c|}{ During fermentation } \\
\hline Pichia kudriavzevii Sample12 & KY794726 & 100 & 0 & 100 \\
\hline Pichia kudriavzevii Sample16 & KY794727 & 100 & 0 & 100 \\
\hline Pichia kudriavzevii Sample22 & KY794723 & 99.8 & $4.69 \mathrm{e}-171$ & 99.7 \\
\hline Pichia kudriavzevii Sample44 & KY794724 & 100 & 0 & 100 \\
\hline Pichia kudriavzevii Sample46 & KY794725 & 99.8 & $2.64 \mathrm{e}-174$ & 99.7 \\
\hline Saccharomyces cerevisiae Sample6 & KY794728 & 99.7 & 0 & 99.5 \\
\hline Saccharomyces cerevisiae Sample7 & KY794729 & 99.8 & 0 & 99.5 \\
\hline Saccharomyces cerevisiae Sample8 & KY794730 & 99.8 & 0 & 99.7 \\
\hline Saccharomyces cerevisiae Sample10 & KY794731 & 99.8 & 0 & 99.5 \\
\hline Saccharomyces cerevisiae Sample13 & KY794732 & 99.8 & 0 & 99.7 \\
\hline Saccharomyces cerevisiae Sample14 & KY794733 & 99.8 & 0 & 99.6 \\
\hline Saccharomyces cerevisiae Sample19 & KY794734 & 99.8 & 0 & 99.7 \\
\hline Saccharomyces cerevisiae Sample20 & KY794735 & 99.6 & 0 & 99.3 \\
\hline Saccharomyces cerevisiae Sample21 & KY794736 & 99.8 & 0 & 99.6 \\
\hline Saccharomyces cerevisiae Sample23 & KY794737 & 99.8 & 0 & 99.6 \\
\hline Saccharomyces cerevisiae Sample24 & KY794738 & 99.2 & 0 & 99.6 \\
\hline Saccharomyces cerevisiae Sample25 & KY794739 & 99.6 & 0 & 99.2 \\
\hline Saccharomyces cerevisiae Sample26 & KY794740 & 99.7 & 0 & 99.6 \\
\hline Saccharomyces cerevisiae Sample29 & KY794741 & 99.8 & 0 & 99.6 \\
\hline Saccharomyces cerevisiae Sample30 & KY794742 & 99.3 & 0 & 99.6 \\
\hline Saccharomyces cerevisiae Sample 31 & KY794743 & 99.8 & 0 & 99.6 \\
\hline Saccharomyces cerevisiae Sample 32 & KY794744 & 99.8 & 0 & 99.6 \\
\hline Saccharomyces cerevisiae Sample33 & KY794745 & 99.7 & 0 & 99.4 \\
\hline Saccharomyces cerevisiae Sample34 & KY794746 & 99.8 & 0 & 99.6 \\
\hline Saccharomyces cerevisiae Sample37 & KY794747 & 99.8 & 0 & 99.6 \\
\hline Saccharomyces cerevisiae Sample39 & KY794748 & 99.8 & 0 & 99.6 \\
\hline Saccharomyces cerevisiae Sample 40 & KY794749 & 99.8 & 0 & 99.6 \\
\hline Saccharomyces cerevisiae Sample43 & KY794750 & 99.8 & 0 & 99.5 \\
\hline Saccharomyces cerevisiae Sample 48 & KY794751 & 99.8 & 0 & 99.6 \\
\hline Torulaspora delbrueckii Sample36 & KY794752 & 99.9 & 0 & 99.9 \\
\hline Torulaspora delbrueckii Sample38 & KY794753 & 99.9 & 0 & 99.9 \\
\hline Trichosporon asahii Sample42 & KY794754 & 100 & 0 & 100 \\
\hline
\end{tabular}

Saccharomyces cerevisiae had the largest number of isolates in the process we investigated (75.0\%), being present from start to finish. The presence of $S$. cerevisiae contributes to the improvement of the sensory characteristics of cocoa-based beverages [22]. Also, it reduces the concentration of lactic acid, hydrogen peroxide removal and favouring the production compounds to growth other bacteria [23, 24]. In Cuba, S. cerevisiae is prominent at the start of the fermentation process, mostly if initiated $48 \mathrm{~h}$ after harvesting [20]. Probably this occurs due to the release of sugars surrounding the fruit flesh, which is the substrate for yeast proliferation $[6$, $25]$. 
A recent review [3], highlighted that in the last two years (2018-2020), S. cerevisiae proved to be an excellent option for obtaining cocoa beans with adequate fermentation as low levels of acidity, acceptable levels of phenolic compounds and protection against aflatoxins.

The species Pichia kudriavzevii was reported in many cocoa seed fermentation studies in different countries such as Ghana, Mexico, Ivory Coast [3, 4]. Meersman et al. (2013) [26] showed that Pichia species were present, but not to the same extent as $S$. cerevisiae. The authors indicate that both species support $\mathrm{pH}$ and temperature variations. $P$. kudriavzevii was reported in the Amazon by Serra et al. (2019) [9]. Pichia kudriavzevii, like P. manshurica, can produce many volatile compounds such as alcohols, aldehydes and esters, that are important for the final product quality [27].

The first report of the isolated yeasts in the Brazilian Amazon was carried out in Medicilândia and Tucumã [8]. The authors also founded S. cerevisiae and P. kudriavzevii during the natural cocoa fermentation, elucidating that these species are common in the Amazon region.

For the first time, inocula with $P$. kudriavzevii were used for the fermentation of cocoa beans in the Amazon [28]. In this study, the authors associated this species with S. cerevisiae (with a proportion 1:1) and obtained cocoa beans with low levels of putrefactive amines and acidity, higher levels of $\mathrm{pH}$, a good amount of methylxanthines and phenolic compounds, making it a good option for the use of cocoa seed fermentation, unlike a fermentation without the inocula additionor only with S. cerevisiae or $P$. kudriavzevii.

Torulaspora delbrueckii was used as a culture starter by Visintin et al. (2017) [29]. This yeast species associated with $S$. cerevisiae produced fermented almonds with a different aromatic profile, becoming another alternative for use.

On the other hand, a specie is widely used as a starter crop in the last two years, precisely because it provides characteristics peculiar to fermented almonds. In the studies by MotaGutierrez et al. (2018) [30] and Santos et al. (2020) [31], this yeast species was also able to reduce fermentation times and acidity levels of the final product [3], which could be seen in the present study.

\subsection{Physico-chemical analyses of the cocoa beans during fermentation}

The results of the physical-chemical analysis and counting of yeasts present in fermentation are shown in Table 2.

An increase in temperature was observed, especially after $24 \mathrm{~h}\left(40.7^{\circ} \mathrm{C}\right)$ and until $48 \mathrm{~h}$. An increase in total acidity was verified after the first $48 \mathrm{~h}$ due to microorganisms' activity, although a reduction was detected after $72 \mathrm{~h}$ of the fermentation process. There were no significant differences in moisture, ash, fat and protein analyses $(p>0.05)$ between the first and the seventh days of the process. During the first $48 \mathrm{~h}$ of fermentation, yeasts have expressive participation while transforming pulp fermentable sugar (glucose) and other components into ethanol [32]. This intense activity elevates the temperature, which is essential for killing the embryo and directly influencing product quality [6]. The consumption of the citric acid in the pulp by the lactic acid bacteria together yeasts in the first times of fermentation and the $\mathrm{pH}$ values of the pulp provides a favourable environment for the subsequent proliferation of lactic and acetic bacteria $[32,33]$.

Acidity is consequential for the fermented seeds' market value because it influences protease activity, which is highest at $\mathrm{pH} 5.0$ to 5.5. Protease activity is essential for promoting hydrolysis of proteins responsible for the desirable chocolate flavour [13]. The proposal of a Cocoa Index [34] suggested a combination of many different chemical parameters (fat, titratable acidity, total phenolic, catechin and epicatechin, organic acids and heavy metals) as an index of fermentation quality that directly influence the product's flavour and aroma. According this Cocoa Index, the appropriate $\mathrm{pH}$ and TTA values must be from 5.60 to 6.57 and from 10.53 to $19.37 \mathrm{mEq}$ $\mathrm{NaOH} / 100 \mathrm{~g}$, respectively. The fermentation reported here had $11.21 \mathrm{mEq} \mathrm{NaOH} / 100 \mathrm{~g}$ (Table 2), indicating its high quality. 
Table 2. Means of physico-chemical analyses and yeast counting during natural cocoa fermentation in Tomé-Açu, PA, Brazil.

\begin{tabular}{|c|c|c|c|c|c|c|c|c|}
\hline $\begin{array}{c}\text { Hours of } \\
\text { Fermentation } \\
\text { (h) }\end{array}$ & $\begin{array}{c}\text { Temperature of } \\
\text { Fermentation } \\
\left({ }^{\circ} \mathrm{C}\right)\end{array}$ & pH & $\begin{array}{c}\text { Titratable } \\
\text { acidity (meq. } \\
\text { NaOH } 0.1 \text { N/100 g) }\end{array}$ & $\begin{array}{c}\text { Moisture* } \\
(\%)\end{array}$ & $\begin{array}{c}\text { Ashes }^{*} \\
(\%)\end{array}$ & $\begin{array}{c}\text { Lipids* } \\
(\%)\end{array}$ & $\begin{array}{l}\text { Proteins }^{*} \\
(\%)\end{array}$ & $\begin{array}{c}\text { Yeast } \\
\text { Counting } \\
\left(\log \mathrm{CFU} \mathrm{g^{-1 }}\right)\end{array}$ \\
\hline 0 & $29.0 \pm 0.78^{c}$ & $5.93 \pm 0.51^{\mathrm{ab}}$ & $11.54 \pm 1.76^{\mathrm{d}}$ & $39.42 \pm 0.88$ & $2.43 \pm 0.07$ & $48.31 \pm 0.99$ & $12.92 \pm 0.33$ & 7.20 \\
\hline 4 & $30.1 \pm 0.63^{c}$ & $5.99 \pm 0.07^{\mathrm{ab}}$ & $12.59 \pm 3.34^{\mathrm{d}}$ & n.a. & n.a. & n.a. & n.a. & 7.45 \\
\hline 8 & $31.5 \pm 0.85^{b c}$ & $5.97 \pm 0.12^{\mathrm{ab}}$ & $13.34 \pm 2.03^{\mathrm{cd}}$ & n.a. & n.a. & n.a. & n.a. & 7.08 \\
\hline 24 & $40.7 \pm 1.96^{\mathrm{a}}$ & $4.68 \pm 0.15^{\mathrm{cd}}$ & $41.62 \pm 4.47^{\mathrm{b}}$ & n.a. & n.a. & n.a. & n.a. & 9.15 \\
\hline 32 & $41.0 \pm 0.93^{\mathrm{a}}$ & $4.51 \pm 0.15^{\mathrm{cd}}$ & $46.60 \pm 5.74^{\mathrm{ab}}$ & n.a. & n.a. & n.a. & n.a. & 5.61 \\
\hline 48 & $42.1 \pm 0.61^{\mathrm{a}}$ & $4.43 \pm 0.14^{\mathrm{d}}$ & $52.3 \pm 2.35^{\mathrm{a}}$ & n.a. & n.a. & n.a. & n.a. & 7.20 \\
\hline 72 & $39.0 \pm 1.34^{\mathrm{a}}$ & $4.79 \pm 0.22^{\mathrm{cd}}$ & $38.60 \pm 1.65^{\mathrm{b}}$ & n.a. & n.a. & n.a. & n.a. & 9.74 \\
\hline 96 & $34.3 \pm 1.52^{\mathrm{b}}$ & $5.45 \pm 0.36^{\mathrm{bc}}$ & $23.59 \pm 1.51^{\mathrm{c}}$ & n.a. & n.a. & n.a. & n.a. & 7.23 \\
\hline 120 & $29.3 \pm 0.95^{c}$ & $5.96 \pm 0.35^{\mathrm{ab}}$ & $15.89 \pm 1.87^{\mathrm{cd}}$ & n.a. & n.a. & n.a. & n.a. & 6.11 \\
\hline 144 & $29.3 \pm 0.81^{\mathrm{c}}$ & $6.35 \pm 0.36^{\mathrm{ab}}$ & $13.84 \pm 1.21^{\mathrm{cd}}$ & n.a. & n.a. & n.a. & n.a. & 5.81 \\
\hline 168 & $30.8 \pm 0.60^{c}$ & $6.69 \pm 0.28^{a}$ & $11.21 \pm 1.97^{\mathrm{d}}$ & $40.57 \pm 0.43$ & $2.24 \pm 0.24$ & $48.58 \pm 0.80$ & $12.53 \pm 0.35$ & 5.18 \\
\hline
\end{tabular}

Means \pm standard deviation with different letters in the same column are statistically different (Tukey test, $p \leq 0.05$ ).

${ }^{1}$ meq. $\mathrm{NaOH} 0.1 \mathrm{~N} / 100 \mathrm{~g}$ : milliequivalent sodium hydroxide solution $0.1 \mathrm{~N}$ per $100 \mathrm{~g}$ sample.

n.a.: not analyzed because during the fermentation process, these variables does not vary statistically.

*: in dry base 
Other publications have reported a lower $\mathrm{pH}$ of the fermented product. Some authors [35] found that initial $\mathrm{pH}$ values ranged between 4.5 and 4.0. The studies of Camu et al. (2007) [5], Samagaci et al. (2014) [36] and Arana-Sánchez et al. (2015) [2], also reported initial pH values lower than this study. The behaviour of $\mathrm{pH}$ is a strong evidence that the microbiota in Amazon cocoa fermentation conduce to a distinct fermentation process when compared with studies conducted in other countries.

The content of lipids was below that reported by Tuenter et al. (2020) [37] carried out on the National variety and all, well below that reported by Afoakwa et al. (2008) [38] for the Forastero variety. However, at the same time that the fermentation and drying process does not seem to influence the variation in fat content, the variety of the fruit should not be the only factor to be studied [39]. The values are within the Cocoa Index proposal, which recommends lipids levels above $30 \%$ to consider fermented cocoa beans of good quality [34].

High levels of total lipids associated with fermentation and prolonged storage times can trigger the high activity of lipase enzymes that act in the breakdown of triglycerides providing an increase in the amount of free fatty acids, thus promoting an increase in the production of sour almond notes [40].

Alcohols are formed by the metabolization of fermentable sugars present in cocoa pulp by yeasts and some lactic acid bacteria $[4,6]$. However, some studies point to their formation due to thermal degradation of amino acids $[41,42]$ which can probably give desirable notes to chocolate as a final product in this study.

\section{CONCLUSIONS}

In this study, we identified the diversity of four yeast species that act during the cocoa fermentation process in the Brazilian Amazon region: Saccharomyces cerevisiae, Torulaspora delbrueckii, Pichia kudriavzevii and Trichosporon asahii. Knowing the current microbiota is important to propose several other studies in the region, as already happens with the production of starter cultures, thus being a possibility for obtaining fermented cocoa beans with characteristics of the region. For this, establish the role that each yeasts species plays on cocoa fermentation is the possibility for future studies. It is important to note that the bacterial diversity also plays an essential role in fermentation, but this was not evaluated in the present study.

\section{ACKNOWLEDGMENTS}

This study was financed by Instituto Tecnológico Vale - Desenvolvimento Sustentável (ITV DS/Cacau P2) (Brazil). The authors wish to thank the Instituto Evandro Chagas (IEC/SVS/MS) for the PCR analyses, the Programa de Pós-graduação em Ciência e Tecnologia de Alimentos of the Federal University of Pará (PPGCTA/UFPA) for providing the infrastructure and Mr. Michinori Konagano for the great technological support. G. Oliveira is a CNPq fellow (307479/2016-1).

\section{REFERENCES}

1. Hamdouche Y, Meile JC, Lebrun M, Guehi T, Boulanger R, Teyssier C, et al. Impact of turning, pod storage and fermentation time on microbial ecology and volatile composition of cocoa beans. Food Res Int. 2019;119:477-91, doi: 10.1016/j.foodres.2019.01.001

2. Arana-Sánchez A, Segura-García LE, Kirchmayr M, Orozco-Ávila I, Lugo-Cervantes E, GschaedlerMathis A. Identification of predominant yeasts associated with artisan Mexican cocoa fermentations using culture-dependent and culture-independent approaches. World J Microbiol Biotechnol. 2015;31(2):35969, doi: 10.1007/s11274-014-1788-8

3. Chagas Junior GCA, Ferreira NR, Lopes AS. The microbiota diversity identified during the cocoa fermentation and the benefits of the starter cultures use: an overview. Int J Food Sci Technol. 2020:1-9, doi: $10.1111 /$ ijfs. 14740 
4. Figueroa-Hernández C, Mota-Gutierrez J, Ferrocino I, Hernández-Estrada ZJ, González-Ríos O, Cocolin $\mathrm{L}$, et al. The challenges and perspectives of the selection of starter cultures for fermented cocoa beans. Int J Food Microbiol. 2019;301:41-50, doi: 10.1016/j.ijfoodmicro.2019.05.002

5. Camu N, De Winter T, Verbrugghe K, Cleenwerck I, Vandamme P, Takrama JS, et al. Dynamics and biodiversity of populations of lactic acid bacteria and acetic acid bacteria involved in spontaneous heap fermentation of cocoa beans in Ghana. Appl Environ Microbiol. 2007;73(6):1809-24, doi: 10.1128/AEM.02189-06

6. Schwan RF, Wheals AE. The microbiology of cocoa fermentation and its role in chocolate quality. Crit Rev Food Sci Nutr. 2004;44(4):205-21, doi: 10.1080/10408690490464104

7. de Araújo JA, Ferreira NR, da Silva SHM, Oliveira G, Monteiro RC, Alves YFM, et al. Filamentous fungi diversity in the natural fermentation of Amazonian cocoa beans and the microbial enzyme activities. Ann Microbiol. 2019;69:975-987, doi: 10.1007/s13213-019-01488-1

8. Almeida SFO, Silva LRC, Chagas Junior GCA, Oliveira G, Silva SHM, Vasconcelos S, et al. Diversity of yeasts during fermentation of cocoa from two sites in the Brazilian Amazon. Acta Amaz. 2018;49(1):64-70, doi: 10.1590/1809-4392201703712

9. Serra JL, Moura FG, Pereira GV d. M, Soccol CR, Rogez H, Darnet S. Determination of the microbial community in Amazonian cocoa bean fermentation by Illumina-based metagenomic sequencing. LWT. 2019;106:229-39, doi: 10.1016/j.lwt.2019.02.038

10. Globo Rural. Pará retoma liderança na produção brasileira de cacau, com a união de agricultores. Globo Rural [Internet]. 2019 Nov 3 [cited 2020 Mar 20]; Available from: https://g1.globo.com/economia/agronegocios/globo-rural/noticia/2019/11/03/lideranca-na-producaobrasileira-de-cacau-volta-para-casa-no-para-com-a-uniao-de-agricultores.ghtml

11. Daniel H, Vrancken G, Takrama JF, Camu N, De Vos P. Yeast diversity of Ghanaian cocoa bean heap fermentations. FEMS Yeast Res. 2009;9:774-783, doi: 10.1111/j.1567-1364-2009-00520.x

12. Fujita, SI, Senda Y., Nakagushi S, Hashimoto T. Multiplex PCR using internal transcribed spacer 1 and 2 regions for rapid detection and identification of yeasts strains. J Clin Microbiol. 2011;39(10):3617-22, doi: 10.1128/JCM.39.10.3617-3622.2001

13. Ho VTT, Zhao J, Fleet G. Yeasts are essential for cocoa bean fermentation. Int J Food Microbiol. 2014;174:72-87, doi: 10.1016/j.ijfoodmicro.2013.12.014

14. Chang HC, Leaw SN, Huang AH, Wu TL, Chang TC. Rapid identification of yeasts in positive blood cultures by a multiplex PCR method. J Clin Microbiol. 2001;39(10):3466-71, doi: 10.1128/JCM.39.10.3466-3471.2001

15. Chen YC, Eisner JD, Kattar MM, Rassoulian-Barrett SL, Lafe K, Bui U, et al. Polymorphic internal transcribed spacer region 1 DNA sequences identify medically important yeasts. J Clin Microbiol. 2001;39(11):4042-51, doi: 10.1128/JCM.39.11.4042-4051.2001

16. Katoh K, Standley DM. MAFFT multiple sequence alignment software version 7: Improvements in performance and usability. Mol Biol Evol. 2013;30(4):772-80, doi: 10.1093/molbev/mst010

17. Guindon, S, Gascuel, O. A simple, fast, and accurate algorithm to estimate large phylogenies. Syst Biol. 2003;52(5):696-704, doi: 10.1080/10635150390235520

18. Horwitz W, Latimer GW Jr. Official Methods of Analysis of AOAC International. 18th ed. Maryland: Assoc Off Anal Chem Int; 2006. 3172 p.

19. Papalexandratou Z, Falony G, Romanens E, Jimenez JC, Amores F, Daniel H, et al. Species diversity , community dynamics, and metabolite kinetics of the microbiota associated with traditional ecuadorian spontaneous cocoa bean fermentations. Appl. Environ. Microbiol. 2011;77(21):7698-714, doi: 10.1128/AEM.05523-11

20. Fernández Maura Y, Balzarini T, Clapé Borges P, Evrard P, De Vuyst L, Daniel HM. The environmental and intrinsic yeast diversity of Cuban cocoa bean heap fermentations. Int J Food Microbiol. 2016;233:3443, doi: 10.1016/j.iffoodmicro.2016.06.012

21. Crafack M, Mikkelsen MB, Saerens S, Knudsen M, Blennow A, Lowor S, et al. Influencing cocoa flavour using Pichia kluyveri and Kluyveromyces marxianus in a defined mixed starter culture for cocoa fermentation. Int J Food Microbiol. 2013;167(1):103-16, doi: 10.1016/j.ijfoodmicro.2013.06.024

22. Puerari C, Teixeira K, Freitas R. New cocoa pulp-based ke fi r beverages : Microbiological , chemical composition and sensory analysis. Food Res Int. 2012;48(2):634-40, doi: 10.1016/j.foodres.2012.06.005

23. Cheirsilp B, Shimizu H, Shioya S. Enhanced kefiran production by mixed culture of Lactobacillus kefiranofaciens and Saccharomyces cerevisiae. J Biotechnol. 2003;100(1): 42-53, doi: 10.1016/S01681656(02)00228-6

24. Magalhães KT, Pereira MA, Nicolau A, Dragone G, Domingues L, Teixeira JA, et al. Production of fermented cheese whey-based beverage using kefir grains as starter culture: Evaluation of morphological and microbial variations. Bioresour Technol. 2010;101(22):8843-50, doi: 10.1016/j.biortech.2010.06.083 
25. de Melo Pereira GV, Magalhães KT, de Almeida EG, da Silva Coelho I, Schwan RF. Spontaneous cocoa bean fermentation carried out in a novel-design stainless steel tank: Influence on the dynamics of microbial populations and physical-chemical properties. Int J Food Microbiol. 2013;161(2):121-33, doi: 10.1016/j.ijfoodmicro.2012.11.018

26. Meersman E, Steensels J, Mathawan M, Wittocx PJ, Saels V, Struyf N, et al. Detailed analysis of the microbial population in Malaysian spontaneous cocoa pulp fermentations reveals a core and variable microbiota. PLoS One. 2013;8(12): e81559, doi: 10.1371/journal.pone.0081559

27. Koné MK, Guéhi ST, Durand N, Ban-Koffi L, Berthiot L, Tachon AF, et al. Contribution of predominant yeasts to the occurrence of aroma compounds during cocoa bean fermentation. Food Res Int. 2016;89:910-7, doi: 10.1016/j.foodres.2016.04.010

28. Chagas Junior GCA, Ferreira NR, Gloria MBA, Martins LHS, Lopes AS. Chemical implications and time reduction of on-farm cocoa fermentation by Saccharomyces cerevisiae and Pichia kudriavzevii. Food Chem. 2021;338:127834, doi: 10.1016/j.foodchem.2020.127834

29. Visintin S, Ramos L, Batista N, Dolci P, Schwan F, Cocolin L. Impact of Saccharomyces cerevisiae and Torulaspora delbrueckii starter cultures on cocoa beans fermentation. Int J Food Microbiol. 2017;257:3140, doi: 10.1016/j.ijfoodmicro.2017.06.004

30. Mota-Gutierrez J, Botta C, Ferrocino I, Giordano M, Bertolino M, Dolci P, et al. Dynamics and biodiversity of bacterial and yeast communities during fermentation of cocoa beans. Appl Environ Microbiol. 2018;84(19):1-17, doi: 10.1128/AEM.01164-18

31. Santos DS, Rezende RP, dos Santos TF, Marques ELS, Ferreira ACR, Silva ABCE, et al. Fermentation in fine cocoa type Scavina: Change in standard quality as the effect of use of starters yeast in fermentation. Food Chem. 2020;328:7-12, doi: 10.1016/j.foodchem.2020.127110

32. Ozturk G, Young GM. Food Evolution: The impact of society and science on the fermentation of cocoa beans. Compr Rev Food Sci Food Saf. 2017;16(3):431-55. doi: 10.1111/1541-4337.12264

33. De Vuyst L, Leroy F. Functional role of yeasts, lactic acid bacteria and acetic acid bacteria in cocoa fermentation processes. FEMS Microbiol Rev. 2020;fuaa014:432-453, doi: 10.1093/femre/fuaa014

34. Araujo QR, Fernandes CAF, Ribeiro DO, Efraim P, Steinmacher D, Lieberei R, et al. Cocoa quality index - A proposal. Food Control. 2014;46:49-54, doi: 10.1016/j.foodcont.2014.05.003

35. Lagunes Gálvez S, Loiseau G, Paredes JL, Barel M, Guiraud JP. Study on the microflora and biochemistry of cocoa fermentation in the Dominican Republic. Int J Food Microbiol. 2007;114(1):124-30, doi: 10.1016/j.ijfoodmicro.2006.10.041

36. Samagaci L, Ouattara HG, Goualié BG, Niamke SL. Growth capacity of yeasts potential starter strains under cocoa fermentation stress conditions in Ivory Coast. Emir. J Food Agric. 2014;26(10):861-70, doi: 10.9755/ejfa.v26i10.18114

37. Tuenter E, Delbaere C, De Winne A, Bijttebier S, Custers D, Foubert K, et al. Non-volatile and volatile composition of West African bulk and Ecuadorian fine-flavor cocoa liquor and chocolate. Food Res Int. 2020;130:108943, doi: 10.1016/j.foodres.2019.108943

38. Afoakwa EO, Paterson A, Fowler M, Ryan A. Flavor formation and character in cocoa and chocolate: A critical review. Crit Rev Food Sci Nutr. 2008;48(9):840-57, doi: 10.1080/10408390701719272

39. De Vuyst L, Weckx S. The cocoa bean fermentation process : from ecosystem analysis to starter culture development. J. Appl. Microbiol. 2016;121:5-17, doi: 10.1111/jam.13045

40. Afoakwa EO, Quao J, Takrama J, Budu AS, Saalia FK. Chemical composition and physical quality characteristics of Ghanaian cocoa beans as affected by pulp pre-conditioning and fermentation J. Food Sci. Technol. 2011;50(6):1097-1105, doi: 10.1007/s13197-011-0446-5

41. Aprotosoaie AC, Luca SV, Miron A. Flavor chemistry of cocoa and cocoa products-an overview. Compr Rev Food Sci Food Saf. 2016;15(1):73-91, doi: 10.1111/1541-4337-12180

42. Utrilla-Vázquez M, Rodríguez-Campos J, Avendaño-Arazate CH, Gschaedler A, Lugo-Cervantes E. Analysis of volatile compounds of five varieties of Maya cocoa during fermentation and drying processes by Venn diagram and PCA. Food Res Int. 2020;129:108834, doi: 10.1016/j.foodres.2019.108834 